\title{
Dynamics Dakwah Social Tuan Guru in Improving the Religion of the Religious People in the Lombok \\ Community
}

\section{Udin*}

\section{UIN Mataram}

Jl. Gajah Mada No. 100, Kota Mataram, Nusa Tenggara Barat. 83116

\begin{tabular}{l|l|l} 
Submitted: $18^{\text {th }}$ Feb 2020 & Revised: $5^{\text {th }}$ Marc 2020 & Accepted: $4^{\text {th }}$ July 2020
\end{tabular}

\begin{abstract}
In this research, the writer examines the social dynamics of the teachings of Tuan Guru in enhancing religious harmony in the Lombok community. This study also tries to reveal the existence of the Tuan Guru in terms of da'wah, social aspects, preservation of cultural traditions and religious patterns of the Lombok people. This study found that Tuan Guru in Lombok has a very broad position and role, not only in religious aspects, but also in the social, economic and political fields. With the capacity in his possession Tuan Guru gives a social propaganda about the importance of religious harmony, the propaganda is not only done in society but through educational institutions as well as boarding schools
\end{abstract}

Keywords: Dakwah, Religious Harmony, Tuan Guru

\section{INTRODUCTION}

Sociologically the role and function of the Tuan Guru is very vital. He has a position that is not affordable, especially by most lay people. Tuan Guru with all its advantages and however small the scope of the area of influence is still recognized by the community as an ideal figure because of its high cultural and structural position. This reality allows the Tuan Guru to contribute greatly to various problems of public relations. The role of the Tuan Guru is not only limited to the spiritual aspects, but also aspects of broader social life.

Tuan Guru in Lombok society is identified with the religion teacher who teaches religion in the midst of the community and has an honorable position, has an important and strategic role in people's lives. A Tuan Guru is considered to have a depth of knowledge, high spirituality, and morality. Often the Tuan Guru is positioned as an informal leader, which is a place to ask questions, to complain about all problems that are not only religious but extend to economic, social, political and other 
problems. Because of that the figure of Tuan Guru in Lombok is always related to all aspects of life, both political, social and educational aspects, even though he does not directly participate actively or engage in a political party (Kahmad, 2001).

The roles possessed by the Tuan Tuan Guru make him must be aware of where they are (where they are), where he is going / going (where they are going), what to do (what has to be done), how they will carry out the task to complete (how they are going to get the task done). Awareness of where his position determines the steps included in communicating his vision and mission through the resources they have. Tuan Guru who was once only a periphery political actor, and some even as a spectator, is now a ruler. The shift in the teacher's behavior in the political arena would certainly lead to change and the role that must be played, this is certainly not easy, need time to adapt and carry out patterns and forms that are in accordance with the moral character of the Tuan Guru. Tuan Guru who occupies a political position of course must follow the protocol that is already running, a separate dilemma for Tuan Guru pesantren who are accustomed to behaving modestly and flexibly, not fixated with formal rules (Horikoshi, 1997; Kingsley, 2010).

A Tuan Guru should be in the midst of the people, so he can directly know the problems faced by his people, to provide alternative solutions. For Tuan Guru who occupies an executive position, it certainly cannot be carried out easily. The strength of the Tuan Guru traditionally and formally in government if synergized by promoting the interests of the people, will give birth to policies and decisions that bring prosperity to the people, but Tuan Guru is an individual who has a separate community base, is not accustomed to collective work, and tends to be accustomed to getting previlage in the community, so that between one Tuan Guru and another, there is often a road disharmony (Mulia, 2007).

Tuan Guru political behavior is very unique, because he has strong legitimacy in the religious, and social fields at the same time. In carrying out his leadership, the Tuan Guru uses his authority based on his charismatic authority, which, according to Max Weber, is a special ability that exists in a person and is a gift from God. With this charismatic authority, Tuan Guru is recognized as someone who has the ability to lead that is above the ability of the people he leads. This charisma is manifested in the belief and worship of Tuan Guru. The basis of this charismatic authority does not lie in a rule (law). But sourced from the personal Tuan Guru concerned. This charisma is increasing in line with the ability of the Tuan Guru to prove its benefits to the community (Budiharjo, 2004; Marasabessy, 2010). 
Aside from his charismatic authority, Tuan Guru has traditional authority (traditional authority). Weber mentions this authority as the authority possessed by a person or group of people who have long held power in a society. This authority is not caused by the advantages and specificities that a person has, but because he has long held the power so that people really trust him and ingrained in his life. The various political behaviors of the Tuan Guru are the choices and paths taken to participate in the development of humanity, because the best human beings are those who are morally kind and able to benefit others.

Tuan Guru is a leader, not only the leader of the institution he fostered, but Tuan Guru is a leader in the community, the leadership of the teacher is caused by the teacher's effectiveness in the midst of the community, where there are social activities or public activities there. Teachers at the event were eagerly awaited by the community. Because the relationship between the friendship and the interaction between Tuan Guru and the intense community naturally the community made the figure of Tuan Guru as a leader and role model in Lombok society.

In the treaty theory states that leaders who come from ordinary people and initially did not have any ability in terms of leadership, but because of their intense interaction with the environment he finally can appear as a figure of a leader who is reliable and can influence others In the community he leads to achieve the goals set (Dirdjosanjoto, 2009)

The interaction of the Tuan Guru in the midst of the community has a strong influence so that the Tuan Guru is not only an ulama figure or a person who has the ability in the religious sciences, but Tuan Guru is also an informal umaro '(leader) in the community. As in behavioral theory or Behaviorist Theories, it is stated that this theory basically assumes that a person will be able to become a leader if he can combine task orientation and relationship oriented (Kartodirdjo, 2013; Fahrurrozi, 2018).

The role of Tuan Guru in Lombok as role models stands above all groups, they do not side with one particular group's strengths. The leadership role of the Tuan Guru in the Lombok community will disappear when the Tuan Guru enters into one force within a group. The influence of Tuan Guru's charisma in the community becomes meaningless when his authority deviates from what he should do to the community. A Tuan Guru who used to be a charismatic figure, was highly respected, became a role model for society, his existence would become like a normal citizen, when he gave up zuhud and turned into a materialist. When a Tuan Guru does something that deviates that is not in accordance with religious norms and teachings, then the community will stay away from it. 
In this case the task as a teacher who is a public servant, the intensity of the teacher to associate with the community is very high, and the public trust in the teacher is also high, so that the influence of the task or mandate carried by the teacher has created a relationship orientation and influence of the teacher in the middle -the middle of the community is very strong, so Tuan Guru is not only a religious teacher, but Tuan guru is a leader in the community.

As the writer found in the field that Tuan Guru is a person who was raised, so that in every religious events and social events before the teacher was present at the event, the community felt reluctant to start the event because they had to wait for the presence of the Tuan Guru beforehand so that the values of Tuan Guru in the community are very high, therefore the high influence of Tuan Guru on the community is according to the author's analysis of many political parties who want to propose Tuan Guru as party representatives to be nominated as people's representatives.

Seeing the position and role of the noble Tuan Guru who is considered as the nation's teacher in Lombok society and always teaches the people throughout his life without expecting wages, some people think that a Tuan Guru should be enough to act as a protector of the people, guardians of the nation's morals especially in religious life, without involved in political activities, because political life is often colored by intrigue and dirty play that is contrary to the moral character of a Tuan Guru, but because of the desire of Tuan Guru in advancing educational institutions that are managed,then there are some Tuan Guru in Lombok who are in touch with politics and some even become administrators in political parties and gain power with these political motors whose aim is nothing but to be able to advance the educational institutions that he manages, such as Horikoshi Tuan Guru's research results play an active role in the process politics, with various variants and forms of roles (Horikoshi, 1987; Hew, 2018).

Finally, the reality of the position of Tuan Guru in Lombok is always faced with the reality that surrounds it, which has a dual role, a Tuan Guru in Lombok besides being a religious figure and at the same time also as a political figure. And historically this role has played very well by Tuan Guru since the early days of Islam developing in Indonesia until now (Dirdjosanjoto, 1999). However, other statements say that it is not proper for a Tuan Guru to fight for power, but to act as the guardian of the nation's morals, to supervise and advise, while maintaining distance from the authorities. Apart from the pros and cons opinions about the position and role of the teacher in the political arena, history has recorded 
an empirical reality which proves that the position and role of the teacher is very strategic and significant in people's lives, so that there is a great deal of involvement of the teacher in politics despite the form and level of his involvement different. There are those who join hands with the authorities, there are those who are resistant by making resistance movements, there are also those who keep their distance by continuing to position themselves as followers of the people. Tuan Guru is Teachers in Lombok, especially in rural areas, is a local elite that has roots and has a strong influence on people's lives, the magnitude of the influence because it is considered as a local cleric to the population in Lombok. According to Bouwsma this influence had existed since the days of the kingdoms, they were not only religious leaders but also informal leaders, because the position and role of the Tuan Guru were more respectable in the eyes of society than formal leaders (Kartodirdjo, 1983; Lubbe, 1986).

Community obedience to Tuan Guru exceeds their obedience to the government, so that the position of Tuan Guru is culturally very strong and will always intersect with the problems of the global community including with political affairs. In view of the history of politics in Indonesia, the association of ulemas with politics has experienced ups and downs from time to time, on the island of Java, in the days of walisongo the saints backed up fully the Islamic government, even walisongolah who formulated and formed the Islamic kingdom first in Demak, the existence of walisongo at that time was very political. During the Dutch colonial era, the Tuan Guru who politicized or fought against the Dutch was arrested and imprisoned, so that many Tuan Guru were more active in the pesantren environment and lived a Sufi life rather than being active in politics (Yusoff, \& Ahmad, 2011).

Scientifically there are many Tuan Guru in Lombok who do not have a scientific background in the fields of government, health, psychology, administration or in the field of communication, but practically, the Tuan Guru in Lombok has various roles such as Tuan Guru as a consultant, Tuan Guru as a community leader and Tuan Guru as an administrator in educational institutions and in society.

Tuan Guru in Lombok society is divided into two types namely, Tuan Guru Traditional Static Teacher and Tuan Guru Rasional Dynamic Teacher. The traditional static Tuan Guru is the Tuan Guru who still holds and maintains old traditions such as always using sarong, white skullcap and turban in every time attending events and activities both formal and informal, this Tuan Guru also has a characteristic in using a turban. Such teachers are usually escorted by students or students and rarely use communication media such as mobile phones and rarely 
appear in formal government events. Unlike the case with Tuan Guru Rational dynamic teacher, Tuan Guru Rational dynamic teacher has experienced developments in accordance with his era, Tuan Guru Rational dynamic teacher is very familiar with the government and very with technology and progress.

The traditional static teacher has a strong role in rural communities and urban society and society. Tuan Guru has a very high charisma in his community and even some of the Tuan Guru from this group are considered sacred by the community. Many people who come to him to ask for directions and prayers even advice. This teacher does not want to go to the government but is visited by the government. This traditional static teacher is reluctant to ask for government assistance but the government comes to visit his residence. In managing and leading the Tuan Guru boarding school, it does not use bookkeeping management and administration but honesty and trust are the basis of its administration so that donations and government and community assistance to him never use records in the form of receipts or physical evidence of donations due to charisma and trust given by the community to him very high.

Slightly different from the dynamic rational Tuan Guru, this Tuan Guru is close to the government and some even as the government, the aim of the Tuan Guru is to get involved in the government and the government bureaucracy is in the context of guarding morals and ubudiyah, the role of the Guru is very high if he can represent the people and remains a role model for the people. Tuan Guru in Lombok is a figure who gives power and suggestions in every aspect of life because without the presence of Tuan Guru in every event the event is considered less blessing because the prayers and advice that are spoken by Tuan Guru can provide suggestions and spirit for the community People believe that the prayers and suggestions given by the Tuan Guru have a stronger influence than the prayers and suggestions of others.

The role of Tuan Guru in addition to being the leader of an educational institution in his Islamic boarding school, Tuan Guru is also considered as a leader in the Lombok community although the leadership of the Tuan Guru has not been formally recognized in government, in every social event the presence of Tuan Guru is highly awaited by residents so in Lombok's social traditions, Tuan Guru is an informal leader whose leadership period does not have a certain time limit and my role in the government is not bound by certain positions, meaning that as long as the teacher can reflect the morality and role models in the 
community, so long as the Tuan Guru will also be used a role model in society.

Tuan Guru in the Lombok community Lombok as well as a consultant, many community members who came to consult with Tuan Guru about the proper day of the marriage contract, as well as other matters such as residents who came to consult with Tuan Guru how to foster a household that mawaddah sakinah and Rahmah, even the Tuan Guru is also an advisor to mediate households that are almost divorced.

\section{RESULT AND DISCUSSION}

\section{Tuan Guru's Struggle in Promoting Religious Harmony through Islamic Education.}

The struggle of the Tuan Guru is not only for the sake of leadership and power but also for the benefit of religious harmony, so that the existence of Tuan Guru in the midst of the community is in the effort to advance Islam such as in increasing harmony in the religious community.

The capacity of the Tuan Guru in the midst of the community is expected by the community to be able to advance the harmony of the religious community so that the relationship of the Tuan Guru with politics and power can impact on and cohesiveness between religious communities which is managed by both the physical progress of the institution or an increase in the quality of the people they lead. . The success or failure of an educational institution will be largely determined by the level of determination and sincerity of the caregivers namely Tuan Guru in developing da'wah in the community he leads, because it is actually not too excessive if there are many obstacles assessing the Tuan Gurus in the midst of the community is a light in providing an example not only in the Islamic community but also in non-Muslim societies as well.

Persocio-economic developments and rural understanding in a community can be known from the socio-cultural factors that affect the community, socio-cultural differences are a challenge for the Tuan Guru in carrying out his mission in the field of religious harmony, so that in subsequent developments each despite having a different direction, according to the level of needs of the surrounding community but they live in harmony and peace. The Tuan Guru also instills the value of Islamic education in Islamic boarding schools having religious goals in accordance with the personalities of the Tuan Guru, the founder of the pesantren. Setake the teaching method and the material of the book that is taught is determined to what extent the qualities of the kiai and are practiced daily in his life (Dhofier, 1992). 
Da'wah with Islamic education about the importance of religious harmony in the boarding schooln also has a mission loaded with religious content, even a Tuan Guru explains that pesantren is a field of worship for the afterlife, the purpose of which is not proven by statistical and written boards is to avoid the attitude of fun, style and systematic preaching of the Tuan Gurus The teacher in enhancing religious harmony and leadership carried out in the current era is nothing but a logical consequence of the role of the Tuan Guru, the changes and adjustments that occur in the systematics and methods of the Da'wah world show that the vision, mission and leadership and preaching of the Tuan Guru are able to adjust to developments people's lives and national harmony systems,this is a proof that the method of propaganda Tuan Guru can do the renewal of the education system that has been applied for years, even more flexible kiai willing to review religious understanding including the social field and look for new patterns in the leadership cadre in order to prepare for the regeneration of pondok leadership boarding school (Wahid, 2010).

Da'wah methods and systematics developed by the Tuan Guru differ from one another, among Muslims themselves it seems that the Tuna Guru has been regarded as a preacher who is able to preach to give an explanation to the community in the field of religious harmony because harmony in the religious field is very important in the midst of society, both in terms of religious and social aspects, community recognition of its existence which Martin Van Bruinessen considers as one of the great traditions as well as the transmission and internalization of the morality of Muslims (Busyairi, 2016).

However, in addition to the methods and methods of preaching of the Tuan Guru with all his communities, it is also necessary to state some of the challenges ahead faced by the community today so that the methods and systems of the Tuan Guru in the da'wah to the community concerning the establishment of religious harmony are increasing, challenges that Experienced by the Tuan Gurus in increasing harmony among religious communities according to experts is increasingly complex in line with the rapid growth of science and technology, this challenge causes a shift in values related to social science and society in advancing religious harmony in the midst of middle of a society.

The Tuan Gurus are considered successful in preaching to increase religious harmony if in a community, both in Muslim and non-Muslim societies social harmony occurs and good relations occur in a society, and vice versa, the Tuan Gurus are deemed to fail in preaching about 
harmony the religious community if there is a dispute and conflict that can lead to things that are not conducive in the midst of society.

\section{CONCLUSION}

In this concluding chapter the researcher seeks to provide an important point of the research results, namely in the form of conclusions that the researcher can summarize as follows; Tuan Guru is no longer speaking only in the fiqh legal order, but Tuan Guru is also the driving force of religious harmony in Lombok, with the increasingly diverse patterns of the teachings of Tuan Guru in reminding religious harmony, the higher the dynamics of communication between religious communities. The dynamics and propaganda patterns of Tuan Guru vary in increasing religious harmony in Lombok, including by establishing social community cooperation such as through mutual cooperation and sports that move the community and through collaborative training in Islamic boarding schools involving non-Muslims as instructors such as computer technician training and handphone. Evidence of the success of Tuan Guru in improving religious community dredging is that the surrounding community becomes harmonious and far from religious conflicts and social conflicts.

\section{REFERENCES}

Amin, E. (2010). Pluralisme dan Dakwah Damai sebagai Agenda Islam Rahmatan Lil' Alamin. Jakarta: LP3S

Arfani, N. R. (2015). Governance dan Pengelolaan Konflik. Yogyakarta: Magister Studi Kebijakan UGM

Azra, A. (2009). Pendidikan Islam: tradisi dan modernisasi menuju milenium baru, Jakarta: Logos Wacana Ilmu

Blau, M. Peter \& Meyer, M. W. (1997). Birokrasi Masyarakat Modern, Edisi Kedua, Cetakan Pertama, Alih Bahasa Gary Rachman Jusuf. Jakarta: UI-Press.

Bradford, D. K. (2019). Managing Conflict to Improve the Efectiveness of AdHoc Marketing Teams, Departement of Marketing: University of Notre Dame

Bruinessen, M. V. (2008). Rakyat Kecil, Islam dan Politik. Yogyakarta: Bentang Budaya

Budiharjo, M. (2004) Aneka Pemikiran tentang Kuasa dan Wibawa. Jakarta: Sinar Harapan 
Udin

Bungin, B. (2016). Penelitian Kualitatif : Komunikasi, Ekonomi, dan Kebijakan Publik Serta Ilmu-Ilmu Sosial Lainnya. Jakarta: Kencana

Busyairi, H. (2016). Dakwah Kontekstual: Sebuah Refeleksi PemikiranKontemporer. Yogyakarta: Pustaka Pelajar

Dhofier, Z. (1992). Tradisi Pesantren: Studi tentang Pandangan Hidup kiai. Jakarta: LP3ES

Dirdjosanjoto, P. (2009). Memelihara Umat: kiai Pesantren-kiai Langgar di Jawa. Yogyakarta: LKiS

Dwiyanto, A. dkk. (2009). Konflik di Era Otonomi Daerah dalam "Reformasi Tata Pemerintahan dan Otonomi Daerah". Jakarta: LP3ES.

Fahrurrozi. (2018). Tuan guru and social change in Lombok, Indonesia. Indonesia and The Malay World, 46(135), 117-134.

Hew, W. W. (2018). The Art of Dakwah: social media, visual persuasion and the Islamist propagation of Felix Siauw. Indonesia and the Malay World, 46(134), 61-79.

Horikoshi, H. (1987). Tuan Guru dan Perubahan Sosial. Jakarta: P3M

Husin, A. (1999). Philosophical and sociological aspects of da'wah: A study of Dewan Dakwah Islamiyah Indonesia.

Kahmad, D. (2001). Sosiologi Agama. Bandung: PT Remaja Rosdakarya

Kartodirdjo, S. (2008). Elit dalam Perspektif Sejarah. Jakarta: LP3ES

Kingsley, J. J. (2010). Tuan Guru, community and conflict in Lombok, Indonesia (Doctoral dissertation).

Lubbe, G. (1986). Tuan Guru: Prince, Prisoner, Pioneer. Religion in southern Africa, 7(1), 25-35.

Marasabessy, B. (2010). Tuan Guru: The Cape Muslim Philosophy Education System. Hubs-Asia, 10(1).

Mulia, M. (2007). "Menuju Kebebasan Bergama di Indonesia" dalam Bayang-bayang fanatisme: Esai-esai untuk mengenang Nurcholis Majid. Jakarta: Pusat Studi Islam dan Kenegaraan

Sukamto, P. (2015). Pesantren Jalan Menuju Perjuangan. Bandung: Pustaka Jaya

Wahid, S. (2010). "Tugas dan Fungsi Da'i dalam Menyelesaikan Konflik Sosial", Dakwah Ala NU. Tangerang: Mumtaza Nawa Dinamika

Yusoff, I., \& Ahmad, S. (2011). Pembangunan Islam menurut Tuan Guru Dato'Nik Abdul Aziz Nik Mat. 